\title{
Loan Loss Provisioning, Income Smoothing, Signaling, Capital Management and Procyclicality: Does IFRS Matter? Empirical Evidence from Nigeria.
}

\author{
Peterson K Ozili \\ Essex Business School, University of Essex, UK \\ Email: petersonkitakogelu@yahoo.com
}

\author{
Doi:10.5901/mjss.2015.v6n2p224
}

\begin{abstract}
Prior research show that banks have various motivations for influencing loan loss provisions. This study examines these motivations and the behaviour of loan loss provision in relation to the business cycle. After controlling for the impact of Basel regulation on LLP, I find strong evidence for income smoothing, capital management and procyclical LLP behaviour during the voluntary, not mandatory, adoption of IFRS in Nigeria. I find evidence of signaling only after including interaction terms in the model. Additionally, I find that (i) banks increase loan loss provisioning after the implementation of Basel; (ii) banks have some incentive to signal via LLP in the post-IFRS period relative to the pre-IFRS period (iii) banks have joint motivations to manipulate LLP and may face trade-offs in the choice of managing regulatory capital or smoothing income in the post-IFRS period. Overall, I conclude that IFRS reinforces LLP motivations and procyclical patterns. The findings of this paper are relevant to current concerns of accounting standard setters and bank regulators on the current model of loan loss provisioning as well as the on-going debate on the mandatory implementation of IFRS in Nigeria.
\end{abstract}

Keywords: Loan loss provision, Earnings Management, Smoothing, Signaling, Bank Capital, Procyclicality, IFRS.

\section{Introduction}

Provision for bad debt or loan loss provision, hereafter LLP, is a deduction from bank net interest income to cover expected credit losses on bank loan portfolio. Bank regulators continue to stress that loan loss provision should be sufficient to minimize loan loss on bank loan portfolio. However, emerging empirical studies suggests that bank managers may have other incentive(s) to influence or manipulate reported loan loss provision estimates other than mitigating expected credit loss. Though standard setters emphasize transparency in the measurement of provisioning estimates to avoid opportunistic managerial behaviour, studies find that banks may influence LLP to reduce the variability of income (income smoothing), manage regulatory capital, and signal loan quality. Also, studies in the banking literature, argue that bad debt provisioning is procyclical with the business cycle. They argue that banks delay provisions until it is too late. The effect of the 2008 financial crisis has raised debates among regulators and academics about IFRS's backward looking provisioning model.

Motivated by these concerns and the voluntary adoption of IFRS reporting among commercial banks in Nigeria, I examine whether bank managers influence LLP to smooth income, manage capital, signal loan quality and whether provisioning is procyclical with the business cycle during the voluntary adoption of IFRS. Furthermore, I test for joint motivations in the pre- and post-crisis period and IFRS period. First, I predict and find strong evidence for income smoothing in the post IFRS period after controlling for Basel capital regulation. Second, I predict and find strong evidence that banks use LLP to manage regulatory (Tier 1) capital to avoid violating regulatory capital requirements. Third, I find evidence for signaling in the IFRS period. Based on further test, I find evidence that managers may have joint motivations for influencing loan loss provision estimates. Finally, I predict and find that banks delay provisions until a recession materializes.

First, this paper contributes to the accounting choice literature which suggest that managers have various incentives for choosing and influencing some accounting numbers, in this case, loan loss provisions. Second, this paper contributes to the recent literature in favour of the debate to improve the current IFRS provisioning model which is highly criticized for its inherent procyclical pattern. Third, this paper contributes to the banking literature on bank capital adequacy. The literature argues that strong capital buffers ensure that bank capital is sufficient to absorb unexpected losses and external shocks. I find that banks use LLP as a form of capital which can be increased (decreased) when capital is low (high). Fourth, this paper is the first to examine income smoothing, earnings management, signaling and procyclicality of LLP in Nigeria. I provide a developing country evidence for the concerns raised about the validity of 
IFRS's current provisioning model. By employing recent bank data, inferences based on the result may inform financial reporting policies. Finally, this empirical evidence contributes to the current debate that criticizes the recent mandatory implementation of IFRS by the Central bank of Nigeria in 2012.

The remainder of this paper is organized as follows: Section 2 reviews the empirical literature and develops the hypotheses based on the literature review. Section 3 presents the methodology. Section 4 discusses the empirical results. Section 5 concludes.

\section{Literature Review and Hypothesis Development}

\subsection{LLP and earnings management}

Earlier studies documents evidence for earnings management using LLP (Ma, 1988; Hasan and Hunter, 1994; Lobo and Yang, 2001; Hasan and Wall, 2003). Also, the recent literature provide evidence for income smoothing. For example, Kanagaretnam et al., (2004) found that banks use discretionary LLP to smooth income but not to signal private information. Anandarajan et al. (2007) show that publicly traded commercial banks in Australia engage in earnings management practices. Perez et al. (2008) found evidence for income smoothing using 142 Spanish banks from 1986 to 2002. Leventis et al. (2012), using a sample of $91 \mathrm{EU}$ banks, found that income smoothing is more pronounced among risky banks but this smoothing behaviour is less aggressive after implementation of IFRS. In a US study, El Sood (2012) found strong evidence for income smoothing. Balbao et al. (2013), using 9442 US banks from 1999 to 2008, found evidence for income smoothing but suggest that this relationship may be driven by non-linear patterns. Curcio and Hassan (2013) find strong evidence for income smoothing among non-EU credit institutions. They report that EU firms within markets with high protection of creditor right do not smooth income. On the other hand, some studies show conflicting evidence (for example, Wetmore and Brick, 1994; Ahmed et al., 1999). Ahmed et al. (1999) found no evidence to support the income smoothing hypothesis after the implementation of Basel 1. Overall, the literature documents more positive evidence of smoothing via LLP. Therefore, consistent with these studies, I hypothesize that there is a positive relation between LLP and pre- tax and pre-provision earnings in the post-IFRS period. This follows the reasoning that when bank profits is abnormally high (low) banks tend to increase (decrease) LLP either to minimize the volatility of earnings or to avoid regulatory scrutiny (Wall and Koch, 2000). Thus,

H1: A positive relation exist between LLP and pre-tax and pre-provision earnings in the post IFRS period.

\subsection{LLP and signaling}

Managers tend to signal private information about their firm to reduce information asymmetry and to communicate positive inside information to investors (Akerlof, 1970). The literature reports a positive relation between stock returns and abnormal LLPs and a negative relation between normal LLP and stock returns, suggesting that investors perceive LLP as a tool used to signal private information about future firm performance (Wahlen, 1994; Beaver and Engel, 1996; Liu et al. 1997). After controlling for non-discretionary changes in LLP, Wahlen (1994) found a positive relation between discretionary provisions and stock returns and future cash flow which suggest that investors interpret abnormal provisions as a signal of good news rather than as a signal of bad news (high expected credit losses). Liu et al. (1997) reports that investors interpret high LLP as good news when banks are experiencing default problems. Also, they showed that banks, with low regulatory capital ratio in the fourth fiscal year, had positive stock market reaction following unexpected increase in LLP. Kanagaretnam et al. (2005) found that the propensity to signal private information is positively related to the degree of information asymmetry and that undervalued banks use LLP to signal private information about future performance. Bouvatier and Lepetit (2008) in a study of European banks found evidence to support the signaling hypothesis. Curcio and Hasan (2013), investigated earnings management in the context of the capital adequacy among EU banks and non-EU credit institutions. Interestingly, they found that non-Euro area banks use earnings to signal private information to investors. On the other hand, Ahmed et al. (1999) did not find strong evidence to support the signaling hypothesis among US banks. In a study of Spanish commercial banks, Anandarajan et al. (2003) and Perez et al. (2008) both do not find strong evidence to support the signaling hypothesis. Subsequently, Anandarajan et al. (2007) found insufficient evidence to support the signaling theory among Australian banks.

To develop the signaling hypothesis, Wahlen (1994) suggests that LLP will contain some positive signal about loan quality after controlling for other non-discretionary indicators of loan default such as changes in non-performing loans and loan charge-offs. Following this reasoning, if bank managers believe that investors view abnormal increase in LLP as a signal of loan quality, a positive relation between LLP and future earnings can be expected. Also, IFRS emphasizes the 
need to disclose information to investors and other users of financial reports. Therefore, bank managers, under IFRS, might take advantage of this disclosure opportunity, to use LLP to signal loan quality to investors, implying a positive relation. Similar to prior studies, I hypothesize: is expected.

H2: A positive relation between LLP and one-year ahead change in pre-provision earnings in the post IFRS period

\subsection{LLP and regulatory capital management}

Prior studies suggest that, to avoid the cost associated with violating capital regulatory requirements, bank tend to manage regulatory capital using LLP (Whalen, 1994; Ahmed et al., 1999). These studies argue that banks tend to increase (decrease) LLP when regulatory capital is low (high) (Moyer, 1990; Beaver and Engel, 1996; Wall and Koch, 2000). For example, Moyer (1990) finds that managers adjust the timing of LLP to avoid violating bank capital limit. Beatty et al. (1995) argue that LLP influences loan quality and capital management decisions. Similarly, Ahmed et al. (1999) found evidence that banks use LLP to manage capital adequacy ratios to avoid violating minimum capital requirement. Anandarajan et al. (2007) found evidence to support the capital management hypothesis. Bouvatier and Lepetit (2008), investigating the pro-cyclical behavior for 186 European banks, found that banks with low capital use LLP to manage regulatory capital. On the other hand, some country-specific studies find no evidence to support the capital management hypothesis (Perez et al. 2008; Leventis et al., 2011). Leventis et al. (2011), using a sample of 91 banks found no evidence for capital management after the implementation of IFRS.

After the convergence to Basel capital regulation in Nigeria immediately after the crisis, there were costs associated with violating minimum capital requirement. If the cost of violation is perceived to be severe, bank managers may have an incentive to influence regulatory capital ratio via LLP. This is consistent with Ahmed et al. (1999) and Wall and Koch (2000). This incentive will be greater if banks view LLP as a form of capital. Therefore, I hypothesize:

H3: A negative relation between LLP and Tier 1 regulatory capital ratio in the post-IFRS period.

\subsection{LLP and Procyclicality}

Studies report that LLP is negatively related to the business cycle measured by GDP growth rate (Arpa et al., 2001; Laeven and Majnoni, 2003; Bikker and Metzemakers, 2005; Perez et al., 2006; Floro, 2010; Packer and Zhu, 2012). Laeven and Majnoni (2002) found that banks delay provisioning until it is too late, suggesting procyclical LLP behaviour. Bikker and Metzemakers (2005) did not find evidence that banks in OECD countries increased provisions in periods of economic boom in anticipation of a recession. Perez et al. (2006) investigated the determinants of LLP among Spanish banks and found LLP to be procyclical. Beaty and Liao (2009) found that banks delay the timing of provisioning until recessionary periods sets in. They argue that increased loan loss provisioning during a recessionary period further reinforces the recession. Floro (2010) finds procyclical provisioning behaviour of among banks in Philippine but noted that such relationship is influenced in a nonlinear way by bank capitalization. Packer and Zhu (2012), in a study of Asian banks, found that provisioning was procyclical among Japanese bank but countercyclical for banks in India. Therefore, consistent with these literature, I hypothesize that banks delay increased provisioning until a recession sets in. Therefore, I hypothesize:

H4: A positive relation between LLP and change in gross domestic product in the post-IFRS period.

\section{Methodology}

\subsection{Data and sample selection}

The dataset employed in this study were extracted from bank financial statement and World Bank database. Data were carefully reviewed for inconsistencies. Concerning outliers in the data, I did not proceed to exclude data in the upper and lower bounds of the distributions because the data is not large due to the small commercial bank population in Nigeria. Also, I do not want to lose further observations which could deteriorate the validity of inferences made based on the findings. Sample bank inclusion criteria include: (i) bank must have existed from 2002; (ii) bank voluntarily adopted IFRS reporting from 2009; (iii) bank was subject to Basel capital regulatory requirements with the evidence of reporting Tier 1 capital as well as total regulatory capital ratio; (iv) bank must have complete data, otherwise, it is excluded; (v) only commercial banks are included to ensure that sample banks face homogenous investment activities and financing methods, thus, development banks, merchant banks, savings, thrifts and cooperative banks are excluded. A final sample 
of 10 banks for a 12-year period, i.e. 2002-2013 which gives a total of 120 bank-year observations. This period is sufficient enough to capture economic downturn and upturns, financial crisis as well as alternative regulatory regimes (IFRS and Basel).

\subsection{Model Specification}

To test the three hypotheses - income smoothing, regulatory capital and signaling, I adopt a modified model derived from existing models in the literature (Ahmed et al., 1999; Anandarajan, et al., 2007; and Leventis et al., 2011). The modelling of LLP takes the functional form below:

$L L P=f[($ non-discretionary), (discretionary), (control variables)]

For this study, the econometric model adopted is panel-data regression with fixed effects.

LLPi,t = a1 + a2 NPLi,t + a3 LLPi,t-1 + a4 LOANi,t + a5 EBTPi,t + a6 SIGNi,t + a7 GDPRj,t + a8 SIZEi,t + a9 IFRSj + a10 POSTj + a11 EBTP*IFRSi,t + a12 SIGN*IFRSi,t + a13EBTP*MCAPi,t + a14TRC*EBTPi,t + a15TRC*SIGNi,t + a16MCAP*SIGNi,t + a17MCAP*EBTP*SIGNi,t + a18TRC*EBTP*SIGNi,t + a19SIGN*EBTPi,t + $\varepsilon i, t$ Where,

LLP - Loan loss provision divided by total assets for firm $i$ at time $t$

EBTP - Earnings before tax and provision divided by total assets for firm i at time $t$

LLPt-1 - Beginning loan loss provision divided by total asset for firm i at time $t$

NPL - non performing loan divided by total assets for firm i at time $t$

SIGN - one-year ahead change in earnings before tax and provisions for firm i at time $t$

MCAP - Tier I regulatory capital ratio for firm i at time $t$

TRC - Total regulatory capital (Tier $1+$ Tier 2 ) for firm i at time $t$

GDPR- change in Gross domestic product

SIZE - bank size derived as the natural logarithm of total assets for firm i at time $t$

IFRS*EBTP- interactive variable indicating income smoothing in the post IFRS regime for firm $i$ at time $t$

IFRS*SIGN - indicating signaling in the post IFRS period for firm i at time $t$

POST - dummy variable controls for pre-and post-Basel regulation and pre- and post-crisis period.

EBTP*MCAP - indicates income smoothing and Tier 1 capital management for firm i at time $t$

TRC*EBTP - indicates income smoothing and total capital management for firm i at time $t$ firm

TRC`SIGN - indicates income smoothing and Tier 1 capital management for firm i at time $t$

$M C A P^{*} S I G N$ - indicates Tier 1 capital management and signaling for firm $i$ at time $t$

MCAP*EBTP*SIGN - indicates smoothing, signaling and Tier 1 capital management for firm i at time $t$

TRC*EBTP*SIGN - indicates smoothing, signaling and total capital management for firm i at time t

SIGN*EBTP - interactive variable indicating income smoothing and smoothing for firm i at time $t$

\subsection{Variable Description}

The dependent variable is LLP. After controlling for non-discretionary (NPL, LOAN, LLPt-1,) and discretionary influences on LLP (EBTP, SIGN, MCAP), the variables of interest in the main regression are IFRS*EBTP and IFRS*SIGN. Nondiscretionary variables employed are non-performing loans, beginning loan loss provision (LLPt-i), ratio of loans and advances to customers divided by total bank total asset (LOAN). These variables explain external factors beyond managerial control that have an influence on LLP. This is consistent with prior studies (Ahmed et al, 1999; Hasan and Wall, 2004; Bouvatier and Lepetit, 2008; Fonseca and Gonzàles, 2008). NPL controls for non-discretionary influence on specific provisions while LOAN controls for general reserves. A positive sign is expected because when banks predict that loan will go bad, they would increase provision, accordingly. Also, a positive sign is expected on LOAN variable. LLPt-1 should have a negative sign. It follows the reasoning that when banks increase provisions in the previous period, provisions for the current period is unlikely to increase proportionately.

Discretionary influences on LLP include EBTP, MCAP and SIGN variable. Using the EBTP variable to indicate smoothing is consistent with prior studies (e.g. Ahmed et al, 1999; Anandarajan, 2007; Bouvatier and Lepetit, 2008; Fonseca and Gonzàles, 2008; Leventis, et al., 2011; Curcio and Hasan, 2013). A positive sign on the coefficient indicates income smoothing, a negative sign indicates otherwise. Also, Ahmed et al. (1999), Leventis, et al. (2011) and Curcio and Hasan (2013) use the relation between LLP and the ratio of Tier 1 capital before LLP (MCAP) to test the capital management hypothesis. MCAP is measured as Tier 1 capital ratio before LLP divided by minimum capital adequacy ratio. TRC is used as an alternative form of capital. Total regulatory capital (TRC) ratio is the sum of Tier 1 (MCAP) and 
Tier 2 capital and is used to observe whether LLP is used to manage TRC. A negative sign on the MCAP coefficient is expected if poorly capitalized banks increase LLPs to increase bank capital to avoid violating capital requirement, otherwise, positive. Consistent with Ahmed et al. (1999), Bouvatier and Lepetit (2008), Curcio and Hasan (2013), I employ the SIGN variable defined as the one-year ahead change in earnings before taxes and LLPs (that is, EBTPi,t+1 EBTPi,t)/0.5(TAi,t + TAi,t+1). TA represents total asset. I expect that banks may or may not take advantage of the disclosure arbitrage in IFRS to signal loan quality to investors.

POST indicates the change to Basel capital regulation after the financial crisis. This dummy variable takes the value of 1 for post-Basel (or post crisis) period, otherwise 0. I expect increased provisioning after the crisis as a precautionary risk management behaviour among banks. Therefore, I expect a positive sign between LLP and POST. Also, I expect that IFRS dummy variables takes the value of I when banks voluntarily adopted IFRS and 0 , otherwise. In 2009, commercial banks in Nigeria voluntarily adopted IFRS. However, it is difficult to predict this sign because differences in implementation and enforcement of IFRS across countries may significantly affect this relationship. Further, a positive sign on EBTP*SIGN indicates that banks jointly smooth income and signal future prospects, otherwise, negative. A positive sign on EBTP*MCAP and EBTP*TRC indicates greater incentives to smooth income than to manage capital, and vice versa. A negative sign on TRC*SIGN and MCAP*SIGN indicates greater incentives to manage capital than to signal, and vice versa. GDPR tests whether LLP is procyclical with the business cycle. This is consistent with prior studies (Laeven and Majnoni, 2003; Bikker and Metzemakers, 2005; Anandarajan et al., 2007; Fonseca and Gonzàlez, 2008; and, Curcio and Hasan, 2013). A negative sign indicates LLP is procyclical, otherwise, positive. Size is expected to have a positive sign. It follows the reasoning that large banks tend to have larger loan portfolio and will tend to increase provision more.

\section{Discussion of Empirical Results}

\subsection{Descriptive statistics and correlations}

Table 1 present the descriptive statistics for the full sample and pre- and post-IFRS sample period. The mean value of LLP in the pre-IFRS period is 0.028 while for the post-IFRS period (0.02). An increase in mean value of loans to customers loans (LOAN) is observed in the post-IFRS period (0.402) relative to pre-IFRS period (0.281). The mean ratio for profitability is higher in the post-IFRS period $(0.045)$ relative to the pre-IFRS period $(0.036)$. A decrease in bank nonperforming loan is observed in the post IFRS period (0.058) relative to pre-IFRS period (0.72). This might suggests that banks to expect minor loans default in the post-IFRS period relative to the pre-IFRS period due to improved credit risk monitoring system and loan diversification across diverse sectors. Finally, total assets increased in the post-IFRS period (13.74) relative to the pre-IFRS period (12.15). Table 5 provides the Pearson correlation coefficients of the sample variables. In the post IFRS period, LLPS are positively and significantly correlated to EBTP and LOAN. All variables give the expected theoretical sign except MCAP and SIZE. However, these conflicting signs are not statistically significant. Finally, for the entire sample period as shown in Table 3, a significant positive correlation between LLP and POST is observed indicating that Basel capital regime, after the 2008 crisis, led to significant increase in loan loss provisioning among Nigerian banks.

Table 1: Descriptive Statistics

\begin{tabular}{|c|c|c|c|c|c|c|c|c|c|c|}
\hline & \multirow{2}{*}{\multicolumn{2}{|c|}{$\begin{array}{c}\text { Full Sample } \\
2002-2012\end{array}$}} & \multirow{2}{*}{\multicolumn{2}{|c|}{$\frac{\text { Pre-IFRS }}{2002-2007}$}} & \multirow{2}{*}{\multicolumn{2}{|c|}{$\frac{\text { Post-IFRS }}{2009-2013}$}} & \multirow{2}{*}{\multicolumn{2}{|c|}{$\frac{\text { Pre-Crisis }}{2002-2006}$}} & \multicolumn{2}{|c|}{ Post-Crisis } \\
\hline Year & & & & & & & & & 2010 & -2013 \\
\hline Variables & Mean (SD) & Max (Min) & Mean (S.D) & Max (Min) & Mean (S.D) & Max (Min) & Mean (S.D) & Max (Min) & Mean (S.D) & Mean (S.D) \\
\hline LLP & $0.023(0.068)$ & $0.504(-0.103)$ & $0.028(0.09)$ & $0.504(0.0002)$ & $0.02(0.039)$ & $0.168(-0.103)$ & $0.009(0.011)$ & $0.054(0.0002)$ & $0.019(-0.04)$ & $0.168(-0.103)$ \\
\hline NPL & $0.063(0.116)$ & 0.8740 & $0.072(0.141)$ & $0.874(0.001)$ & $0.058(0.091)$ & 0.4890 & $0.059(0.099)$ & $0.549(0.001)$ & $0.038(0.412)$ & 0.3460 \\
\hline LLPT & $0.021(0.067)$ & $0.504(-0.103)$ & $0.009(0.013)$ & $0.054(0)$ & $0.038(0.101)$ & $0.504(-0.104)$ & $0.068(0.007)$ & 0.0310 & $0.019(0.035)$ & $0.124(-0.103)$ \\
\hline LOAN & $0.337(0.048)$ & $0.617(0.002)$ & $0.281(0.114)$ & $0.493(0.002)$ & $0.402(0.118)$ & $0.617(0.155)$ & $0.293(0.109)$ & $0.493(0.007)$ & $0.393(0.122)$ & $0.617(0.155)$ \\
\hline EBTP & $0.04(0.048)$ & $0.362(-0.11)$ & $0.036(0.06)$ & $0.088(-0.027)$ & $0.045(0.071)$ & $0.362(-0.107)$ & $0.039(0.018)$ & $0.088(-0.006)$ & $0.045(0.078)$ & $0.362(-0.107)$ \\
\hline SIGN & $0.009(0.031)$ & $0.121(-0.105)$ & $0.010(0.031)$ & $0.088(-0.105)$ & $0.006(0.032)$ & $0.121(-0.104)$ & $0.014(0.022)$ & $0.088(-0.038)$ & $0.006(0.034)$ & $0.121(-0.104)$ \\
\hline GDPR & 9.923(8.44) & $33.7(3.4)$ & 13.12(10.23) & $33.7(3.4)$ & $5.86(1.31)$ & $7.8(4.3)$ & 15.34(10.95) & $33.7(3.4)$ & $5.6(1.345)$ & $7.8(4.3)$ \\
\hline SIZE & $12.77(1.593)$ & $21.77(9.34)$ & $12.15(1.281)$ & $15.07(9.34)$ & $13.74(1.44)$ & 21.77(11.19) & $11.73(1.347)$ & $15.07(9.34)$ & $13.84(1.56)$ & $21.77(11.19)$ \\
\hline TRC & & & & & $3.442(5.639)$ & $30.56(-1.82)$ & & & $3.636(6.72)$ & $30.56(1.82)$ \\
\hline MCAP & & & & & $1.708(2.236)$ & $4.49(-9.71)$ & & & $1.811(1.422)$ & $4.476(-2.912)$ \\
\hline Obs. & 120 & & & 60 & & 50 & & 50 & & 40 \\
\hline
\end{tabular}


Tier 1 capital than to signal loan quality. This is indicated by the significant negative sign on the MCAP*SIGN coefficient ($1.73, a=10 \%)$. Interestingly, I find strong evidence that banks in Nigeria seem to have no incentive to jointly smooth income and signal loan quality. This is inferred from SIGN*EBTP $(-3.68, a=1 \%)$

\section{Conclusion}

Consistent with Healy and Wahlen (1999), it is important for regulators to understand accrual-based accounting numbers used by bank managers to influence reported earnings, as well as, bank capital. The findings in this study is the first to provide evidence for smoothing, signaling and capital management via LLP in Nigeria. Ahmed et al. (2014) only examined income smoothing via LLP. In the present study, I test whether LLPs is used for capital management, earnings management and signaling in Nigerian banks during the voluntary adoption of IFRS. Overall, I find evidence to indicate that Nigerian banks use LLP to manage capital, smooth reported earnings and signal loan quality in the post-IFRS period. Also, I find increased bank provisioning following the implementation of Basel capital regulation immediately after the 2008 financial crisis. Finally, a robustness analysis show that joint motivations to influence LLP exists, as well as, tradeoffs between two or more motivations. My findings indicate that, during IFRS reporting periods, reported earnings and related accounting numbers do not truly reflect the underlying economic reality of Nigerian banks based on the results. Standard setters and bank regulators (IASB and the Central Bank of Nigeria) might consider the prevalence of these motivations when evaluating the risk profile of banks and how these motivations, if pervasive, might pose systemic risk on the financial system. Finally, it is expected that a policy maker might conclude that these motivations indicate manipulative accounting practices by bank managers, however, policy implications drawn from the results in this study should take into consideration the fact that bank regulatory incentives may also have encouraged these motivations as well. IFRS alone is not to blame. Future research may examine other accounting numbers, accrual-based or based on real activities, which banks might influence to manage earnings and capital.

\section{References}

Ahmed, A. S, Takeda, C., and Thomas, S. (1999), "Bank loan loss provisions: a reexamination of capital management, earnings management and signaling effects", Journal of Accounting and Economics, 28:1-25.

Anandarajan A, Hasan I, Lozano-Vivas A. (2003), "The role of loan loss provisions in earnings management, capital management and signaling: The Spanish experience", Advances in International Accounting, 16: 45-65.

Anandarajan, A., Hasan, I., and McCarthy, C. (2007), "Use of loan loss provisions for capital, earnings management and signaling by Australian banks", Accounting \& Finance, 47 (3): 357-379.

Arpa, M., Giulini, I., Ittner, A., and Pauer, F. (2001), "The influence of macroeconomic developments on Austrian banks: implications for banking supervision", BIS Papers No. 1, 91-116.

Akerlof, G. (1970), "The market for 'lemons': quality uncertainty and the market mechanism”, Quantitative Journal of Economics, 89: 488-500.

Balbao, M., López-Espinosa, G and Rubia, A. (2013), "Nonlinear dynamics in discretionary accruals: An analysis of bank loan-loss provisions", Journal of Banking \& Finance, 37 (12): 5186-5207

Beaver, W., and Engel, E. (1996), "Discretionary behavior with respect to allowances for loan losses and the behavior of security prices", Journal of Accounting and Economics, 22: 177-206.

Beatty, A. and Liao, S. (2009), "Regulatory capital ratios, loan loss provisioning and pro-cyclicality" Working Paper, The Ohio State.

Bikker, J.A., and Metzemakers, P.A.J. (2005), "Bank provisioning behaviour and procyclicality", Journal of International Financial Markets, Institutions and Money, 15: 141-157.

Curcio, D., \& Hasan, I. (2013). Earnings and capital management and signaling: the use of loan-loss provisions by European banks, The European Journal of Finance, 1-25.

El Sood, H.A. (2012), "Loan loss provisioning and income smoothing in US banks pre and post the financial crisis", International Review of Financial Analysis, 25: 64-72.

Floro, D, (2010), "Loan Loss Provisioning and the Business Cycle: Does Capital Matter? Evidence from Philippine Banks." BIS Working Paper

Fonseca, A. R, and González, F. (2008), "Cross-country determinants of bank income smoothing by managing loan-loss provisions", Journal of Banking \& Finance, 32 (2): 217-228.

Hasan, I. and Hunter, W.C. (1999), "Income-smoothing in the depository institutions: An empirical investigation", Advances in Quantitative Analysis of Finance and Accounting, 7: 1-16.

Hasan I \& Wall, L.D (2004), "Determinants of the Loan Loss Allowance: Some Cross-Country Comparisons", The Financial Review, Eastern Finance Association, 39 (1): 129-152.

Healy, P. and Wahlen, J. (1999), "A Review of the Earnings Management Literature and its Implications for Standard Settings", Accounting Horizons, 13: 365-383.

Kanagaretnam, K., Lobo, G.J and Mathieu, R. (2003), "Managerial Incentives for Income Smoothing through Bank Loan Loss Provisions", Review of Quantitative Finance and Accounting, 20: 63-80.

Kanagaretnam, K, Lobo, G. L, and Yang, D (2005), "Determinants of signaling by banks through loan loss provisions", Journal of Business Research, 58: $312-320$.

Kanagaretnam, K. and Lobo, G and Yang, D (2004), "Joint Tests of Signaling and Income Smoothing through Bank Loan Loss Provisions", Contemporary Accounting Research, 21 (4): 843-884.

Laeven, L, and Majnoni, G. (2003), "Loan Loss Provisioning and Economic Slowdowns: Too Much, Too Late", Journal of Financial Intermediation, 12 (2): 
178-197.

Leventis, S and Dimitropoulos, P.E., and Anandarajan, A., (2011), "Loan Loss Provisions, Earnings Management and Capital Management under IFRS: The Case of EU Commercial Banks", Journal of Financial Services Research, 40 (1): 103-122.

Leventis, S., Dimitropoulos, P. E and Anandarajan, A. (2012),"Signalling by banks using loan loss provisions: the case of the European Union", Journal of Economic Studies, 39 (5): 604-618.

Liu, C., Ryan S.G., Wahlen, J.M. (1997), "Differential valuation implications of loan loss provisions across banks and fiscal quarters", The Accounting Review, 72: (1): 133-146.

Lobo, G.J and Yang, D. (2001), "Bank Managers' Heterogeneous Decisions on Discretionary Loan Loss Provisions", Review of Quantitative Finance and Accounting, 16: 223-250.

Ma, C.K. (1988) "Loan loss reserve and income smoothing: The experience in the U.S. banking industry. Journal of Business Finance and Accounting", 15 (4), 487-497.

Moyer, S.E (1990), "Capital Adequacy Ratio Regulations and Accounting Choices in Commercial Banks", Journal of Accounting and Economics, 13: 123154.

Packer, F and Zhu, H (2012) "Loan loss provisioning practices of Asian banks", BIS Working Papers, No 375.

Pérez D, Salas-Fumás V, Saurina, J. (2008) "Earnings and capital management in alternative loan loss provision regulatory regimes", European Accounting Review, 17:423-445.

Wahlen, J. (1994) "The nature of information in commercial bank loan loss disclosures", The Accounting Review, 1: 455-478.

Wall, L., and T.W. Koch, (2000). "Bank Loan-Loss Accounting: A Review of Theoretical and Empirical Evidence", Federal Reserve Bank of Atlanta Economic Review, pp 1-19.

Wetmore J. and J. Brick (1994) "Loan-Loss Provisions of Commercial Banks and Adequate Disclosure: A Note", Journal of Economics and Business, 46: 299-305.

\section{Tables}

Table 3: Robustness Regression

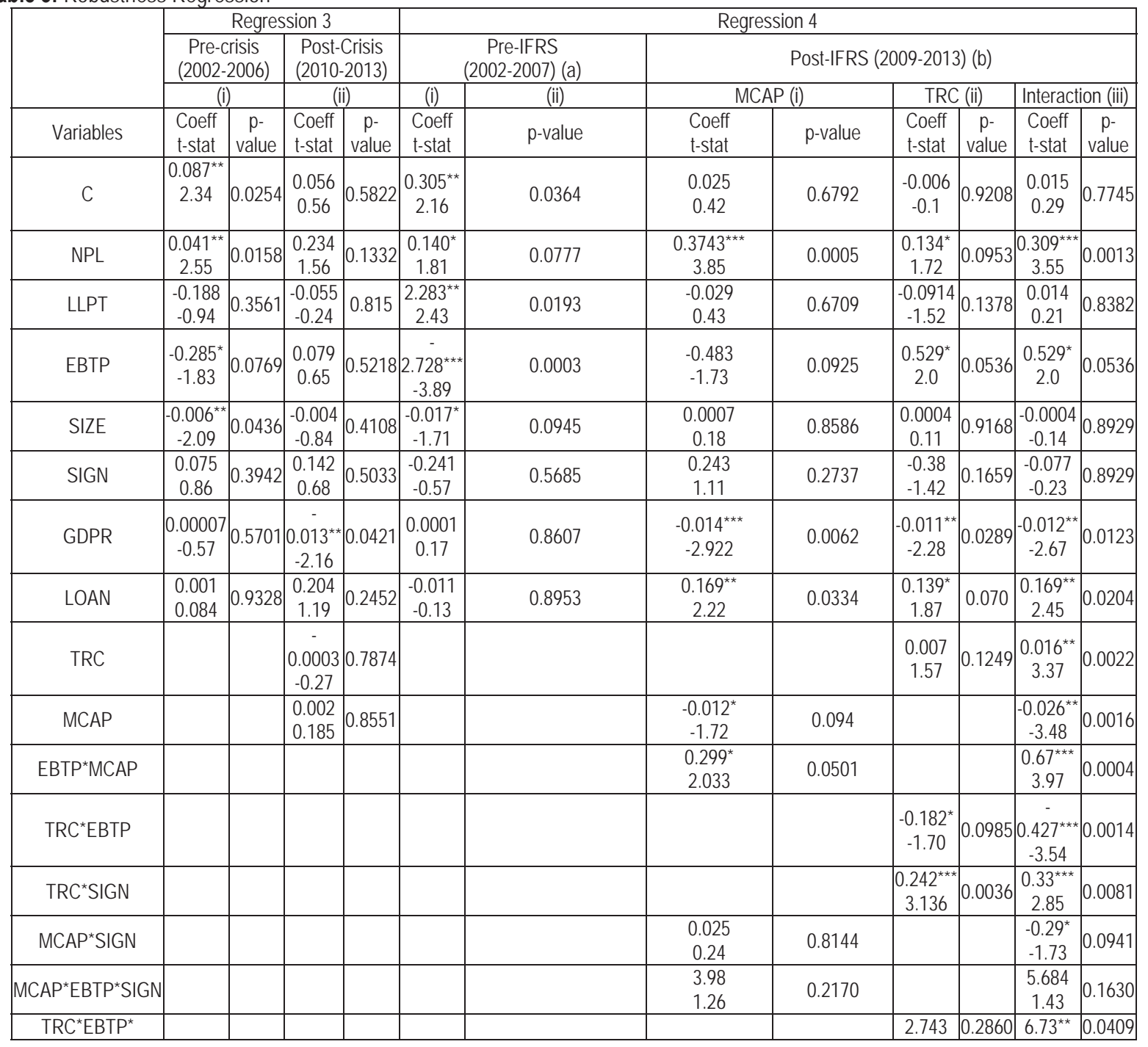




\begin{tabular}{|c|c|c|c|c|c|c|c|c|}
\hline SIGN & & & & & & 1.085 & 2.14 & \\
\hline SIGN*EBTP & & & & $\begin{array}{l}-7.648 \\
-1.37\end{array}$ & 0.1811 & $\begin{array}{l}-6.012 \\
-0.94\end{array}$ & $0.3540 \mid \begin{array}{c}25.81^{\star * \star} \\
-3.68\end{array}$ & 0.0009 \\
\hline $\begin{array}{c}\text { Adj R }{ }^{2} \\
\text { F-stat } \\
\text { P(F-stat) }\end{array}$ & $\begin{array}{l}0.4574 \\
3.58^{\star \star \star} \\
0.0009 \\
\end{array}$ & $\begin{array}{c}0.3301 \\
2.07^{*} \\
0.056 \\
\end{array}$ & $\begin{array}{l}0.6001 \\
6.553 \\
0.000 \\
\end{array}$ & $\begin{array}{c}0.3551 \\
2.69^{\star \star \star} \\
0.008\end{array}$ & & \begin{tabular}{|c|}
0.2824 \\
$2.205^{\star \star}$ \\
0.027 \\
\end{tabular} & \multicolumn{2}{|c|}{$\begin{array}{l}0.5289 \\
3.75^{\star \star \star} \\
0.0006\end{array}$} \\
\hline Obs. & 50 & 40 & 60 & 50 & & 50 & 50 & \\
\hline \multicolumn{9}{|c|}{$\begin{array}{l}\text { Regression 3(i) \& 4(a): LLP = NPL + LLPt-1 + LOAN+ EBTP+ SIGN+ SIZE+ GDPR } \\
\text { Regression b (i): LLP = NPL + LLPt-1 + LOAN + EBTP + SIGN + MCAP + SIZE + GDPR } \\
\text { Model b(ii) (excludes MCAP): LLP = NPL + LLPt-1 + LOAN + EBTP + SIGN + TRC + SIZE + GDPR } \\
\text { Model b(iii) (combines TRC+MCAP): LLP = NPL + LLPt-1 + LOAN+ EBTP + SIGN + MCAP + TRC+ SIZE + GDPR + EBTP*MCAP + TRC*EBTP + } \\
\text { TRC*SIGN + MCAP*SIGN + MCAP*EBTP*SIGN + TRC*EBTP*SIGN+SIGN*EBTP }\end{array}$} \\
\hline \multicolumn{9}{|c|}{$\begin{array}{l}\text { Note: Fixed effects for all regression models, apply. Significant at } 10 \%^{*}, 5 \%{ }^{* \star} \text { and } 1 \% \%^{\star \star \star} \text { (two-tailed test). The pre-and post-crisis regressions } \\
\text { excludes } 2007-2009 \text { bank-year observation to control for the severe impact of the crisis on balance sheet of Nigerian banks }\end{array}$} \\
\hline
\end{tabular}

Table 4: Full Sample period pearson correlation coefficients

\begin{tabular}{|c|c|c|c|c|c|c|c|c|c|c|}
\hline \multicolumn{11}{|c|}{ Correlation } \\
\hline Probability & LLP & NPL & LLPt-1 & LOAN & EBTP & SIGN & GDPR & POST & IFRS & SIZE \\
\hline LLP & 1.000 & & & & & & & & & \\
\hline NPL & $\begin{array}{c}0.515^{\star \star \star} \\
0.000\end{array}$ & 1.000 & & & & & & & & \\
\hline LLPt-1 & $\begin{array}{l}0.048 \\
0.598\end{array}$ & $\begin{array}{l}0.267 \\
0.003\end{array}$ & 1.000 & & & & & & & \\
\hline LOAN & $\begin{array}{l}-0.101 \\
0.273\end{array}$ & $\begin{array}{l}-0.041 \\
0.658\end{array}$ & $\begin{array}{l}0.111 \\
0.229\end{array}$ & $\begin{array}{c}1.000 \\
---.\end{array}$ & & & & & & \\
\hline EBTP & $\begin{array}{c}-0.027 \\
0.769\end{array}$ & $\begin{array}{l}0.021 \\
0.823\end{array}$ & $\begin{array}{l}0.032 \\
0.731\end{array}$ & $\begin{array}{l}0.298 \\
0.001\end{array}$ & 1.000 & & & & & \\
\hline SIGN & $\begin{array}{l}0.114 \\
0.217\end{array}$ & $\begin{array}{l}0.181 \\
0.048\end{array}$ & $\begin{array}{l}0.087 \\
0.342\end{array}$ & $\begin{array}{l}0.055 \\
0.554\end{array}$ & $\begin{array}{c}0.0465 \\
0.614\end{array}$ & 1.000 & & & & \\
\hline GDPR & $\begin{array}{c}-0.091 \\
0.322\end{array}$ & $\begin{array}{l}0.044 \\
0.635\end{array}$ & $\begin{array}{r}-0.097 \\
0.287\end{array}$ & $\begin{array}{l}-0.145 \\
0.112\end{array}$ & $\begin{array}{l}0.019 \\
0.838\end{array}$ & $\begin{array}{l}0.017 \\
0.853\end{array}$ & $\begin{array}{c}1.000 \\
----\end{array}$ & & & \\
\hline POST & $\begin{array}{c}0.182^{\star *} \\
0.047\end{array}$ & $\begin{array}{l}0.052 \\
0.576\end{array}$ & $\begin{array}{c}0.1934 \\
0.034\end{array}$ & $\begin{array}{l}0.374 \\
0.000\end{array}$ & $\begin{array}{l}0.017 \\
0.853\end{array}$ & $\begin{array}{l}0.0954 \\
0.3002\end{array}$ & $\begin{array}{c}-0.4749 \\
0.000\end{array}$ & $\begin{array}{c}1.000 \\
----\end{array}$ & & \\
\hline IFRS & $\begin{array}{c}-0.035 \\
0.705\end{array}$ & $\begin{array}{c}-0.043 \\
0.642\end{array}$ & $\begin{array}{l}0.211 \\
0.021\end{array}$ & $\begin{array}{l}0.439 \\
0.000\end{array}$ & $\begin{array}{l}0.075 \\
0.416\end{array}$ & $\begin{array}{c}-0.064 \\
0.485\end{array}$ & $\begin{array}{c}-0.408 \\
0.000\end{array}$ & $\begin{array}{l}0.845 \\
0.000\end{array}$ & $\begin{array}{c}1.000 \\
---\end{array}$ & \\
\hline SIZE & $\begin{array}{c}-0.055 \\
0.546\end{array}$ & $\begin{array}{c}-0.081 \\
0.381\end{array}$ & $\begin{array}{c}0.1165 \\
0.205\end{array}$ & $\begin{array}{l}0.239 \\
0.009\end{array}$ & $\begin{array}{c}-0.155 \\
0.091\end{array}$ & $\begin{array}{c}-0.103 \\
0.261\end{array}$ & $\begin{array}{c}-0.386 \\
0.000\end{array}$ & $\begin{array}{l}0.548 \\
0.000\end{array}$ & $\begin{array}{l}0.517 \\
0.000\end{array}$ & 1.000 \\
\hline
\end{tabular}

Table 5: Correlation Post IFRS

\begin{tabular}{|c|c|c|c|c|c|c|c|c|c|c|}
\hline \multicolumn{11}{|c|}{ Correlation } \\
\hline Probability & LLP & NPL & LLPt-1 & LOAN & EBTP & SIGN & MCAP & TRC & GDPR & SIZE \\
\hline LLP & 1.000 & & & & & & & & & \\
\hline NPL & $\begin{array}{c}0.248^{\star} \\
0.083\end{array}$ & & & & & & & & & \\
\hline LLPt-1 & $\begin{array}{c}-0.069 \\
0.631\end{array}$ & $\begin{array}{c}0.460^{* * *} \\
0.001\end{array}$ & & & & & & & & \\
\hline LOAN & $\begin{array}{c}0.358^{\star \star} \\
0.011\end{array}$ & $\begin{array}{l}0.099 \\
0.489\end{array}$ & $\begin{array}{l}0.079 \\
0.583\end{array}$ & & & & & & & \\
\hline EBTP & $\begin{array}{c}0.419 \star \star \star \\
0.002\end{array}$ & $\begin{array}{l}0.292 \\
0.039\end{array}$ & $\begin{array}{l}0.031 \\
0.828\end{array}$ & $\begin{array}{l}0.350 \\
0.013\end{array}$ & & & & & & \\
\hline SIGN & 0.155 & -0.003 & 0.212 & 0.129 & 0.069 & & & & & \\
\hline MCAP & 0.114 & $\begin{array}{l}-0.544 \\
\end{array}$ & $\begin{array}{l}-0.429 \\
\end{array}$ & 0.428 & 0.018 & 0.169 & & & & \\
\hline & 0.432 & 0.000 & 0.002 & 0.002 & 0.903 & 0.238 & & & & \\
\hline TRC & 0.011 & 0.058 & 0.053 & 0.133 & -0.0004 & 0.079 & 0.222 & & & \\
\hline & 0.94 & 0.687 & 0.714 & 0.354 & 0.997 & 0.585 & 0.122 & & & \\
\hline GDPR & -0.137 & 0.381 & 0.191 & 0.229 & -0.030 & -0.189 & -0.011 & 0.074 & & \\
\hline & 0.342 & 0.007 & 0.185 & 0.109 & 0.834 & 0.187 & 0.937 & 0.607 & & \\
\hline SIZE & -0.046 & -0.269 & 0.0134 & 0.112 & -0.249 & -0.161 & 0.168 & -0.059 & -0.145 & \\
\hline & 0.748 & 0.058 & 0.926 & 0.438 & 0.081 & 0.264 & 0.243 & 0.679 & 0.315 & \\
\hline
\end{tabular}

